\title{
Application of Conferencing Approach to Improve Cooperation Skills of Class IV Elementary School Students
}

\author{
Yoesrina Novia Vini Syafitri, Tatat Hartati ${ }^{1}$, Tatang Syaripudin ${ }^{2}$ \\ Pedagogic Department Primary School Teacher Education Study Program, Faculty of Science \\ Education, Indonesian Education University \\ e-mail: yoesrinanovia06@gmail.com
}

\begin{abstract}
The ability of cooperation is an important aspect of personality and needs to be owned by everyone, especially in group learning. Based on the preliminary results of the learning in the fourth grade of CST SDN shows that the ability of student cooperation is still low. This is because the teacher does not give clear instructions about learning in groups, how to learn in groups, how to divide the tasks for each member of his group, and the teacher does not motivate the students to be able to work with friends of his group. This study aims to describe the application of the conferencing approach to improving the ability of cooperation of fourth-grade elementary school students. The research method used is the research of the class action model of Kemmis and Mc Taggart. The subjects of this study were 38 students of grade IV SDN CST. Data collection techniques used were observations and field notes. Qualitative data were taken using techniques from Miles and Huberman which consist of data reduction, data presentation and conclusion, and verification. While the quantitative data is taken using the statistic average and percentage. The results show that the application of the conferencing approach can improve students' cooperative ability, especially on group learning in the classroom.
\end{abstract}

Keywords: cooperative ability, conferencing, classroom action research

\section{Introduction}

Basically, humans are social creatures. To develop the potential that exists in him needed help and guidance from other humans. In an effort to develop these potentials, education is needed. This is in line with Law Number 20 the Year 2003 concerning the National Education System Article 1 states that "Humans need education in their lives". Because in essence:

Education is a conscious and planned effort to create an atmosphere of learning and learning process so that students actively develop their potential to have spiritual strength, self-knowledge, personality, noble character, and the skills needed by themselves, society, nation, and state. (UUSPN No.20 of 2003)

The realization of the potential for collaboration can actually be realized in learning in the classroom. Because Widiasworo (2017, p. 80) states that "collaboration in the classroom, especially in learning will foster interpersonal relations skills." Interaction occurs between students, especially in a group or cooperative learning. Cooperation in group activities will certainly have a positive impact on students, especially in the 
mastery of the material will also make learning meaningful. This is consistent with the opinion of Johnson \& Johnson (in Isjoni, 2011, p. 17) that group or cooperative learning is "grouping students in class into small groups so that students can work together with the maximum ability they have and learn from each other in the group."

Based on the results of the preliminary study, it is known that the ability of the fourth-grade students to cooperate is in the criteria of needing guidance, with a percentage of $40.57 \%$. Of these percentages 22 students are at the level of cooperative ability need guidance, 16 students are at a sufficient level. This is due to the teacher carrying out learning classically. The teacher has used the group learning method, students study into six small groups. The small group consists of six to seven heterogeneous members based on different sexes and academic abilities. When students study in groups students work individually, no discussion or problem is solving together. Also, smart students in groups dominate and underestimate students who are lacking. Therefore, less smart students are only able to copy the work of their friends and do not try to understand how to do it. Smart students also do not have the initiative to teach their friends who do not understand the material being studied. The teacher also does not give clear instructions about learning in groups, how to divide assignments to each group member, and the teacher does not motivate students to be able to work together with group friends. Besides, in preparing the Learning Implementation Plan the teacher applies the lecture method so that the implementation of learning in the classroom cannot develop the cooperative skills of fourth-grade students at SDN CST.

The above problems must be overcome because otherwise, students will experience difficulties in developing their potential. The development of this potential can be realized through cooperation. This is in line with Zaltman's opinion (in Isjoni, 2011, p.24) "students who work together in groups will create friendly friendships and are very influential on individual student behavior".

From the results of the literature study, there is a learning approach that can improve the ability of students to work together, namely the conferencing approach. Conferencing approach is a learning approach where student learning activities begin with students discussing at the beginning level, the middle rank of the teacher guiding the discussion and evaluating, and at the final level students present the results of their group discussions.

This conferencing approach is considered appropriate to be applied to improve students' collaborative abilities. This is because the conferencing approach is an approach that requires individual interaction. Lyesmaya, et al. (in Suherman, 2016, p. 4) explains that "A conferencing approach is a form of approach where conference participants interact and communicate with each other". Also, "the conferencing approach focuses on conferences/trials between students and students (peers) and between students and teachers" (Hartati, 2009, p.4). In essence, the conferencing approach requires learning activities in the classroom to be interactive and communicative, both between students and students and students and teachers. The conferencing approach has several advantages, through the application of this conferencing approach, it can not only improve students' ability to work together, but 
can improve other abilities of students themselves. Therefore, the conferencing approach is seen to be able to improve the ability to work students in grade IV SDN CST.

The above hypothesis is supported by the results of Zia Choerulwildan's research on "The Application of Conferencing Approaches to Improve Discussion Skills of Grade V Elementary School Students" in 2017. The results of the study indicate that there is an increase in discussion skills so that it will affect the ability of the students of class $\mathrm{V}$ SD.

Meanwhile, the results of other studies from Meti Kusuma Dewi (2017) showed that the application of the TGT (team game tournament) type of cooperative learning model could improve the cooperative skills of fifth-grade elementary school students. The results showed that the average cycle I could cooperate with students at $65 \%$, increasing in cycle II by $20 \%$ to $85 \%$. From the results of these studies indicate that there is an increase in the ability to work together by applying group learning

\section{Method}

The method used is classroom action research (CAR). According to Aqib (2017, p. 13), classroom action research can be defined as "a form of research conducted by the teacher in the classroom (school) where he teaches with an emphasis on perfecting or improving the learning process and practice". Meanwhile according to Arikunto (2015, p. 1) "class action research is research that describes the cause and effect of the treatment, as well as describing what happens when the treatment is given and describes the entire process from the initial treatment to the impact of the treatment".

This research model is Kemmis and Mc Taggart's models. The study was conducted in cycles with the following stages.

\subsection{Planning}

The plan is a plan of action that will be taken to correct, improve or change the behavior and attitude as a proposed solution to the problem. Plans are made after analyzing the problem and finding the cause or root of the problem.

\subsection{Action}

Action is what is done by the teacher as an effort to repair, increase or change desired. The action taken is an implementation of the plan that has been prepared.

\subsection{Observation}

Observation is an activity of observation of the actions carried out or imposed on students. In general, observations are made when teaching and learning activities are taking place.

\subsection{Reflection}


Reflection is an activity of studying, seeing and considering the process carried out about the results or impact of actions. Based on the results of this reflection, the teacher can make improvements to the initial plan.

Participants in this study were students of grade IV SDN CS with a total of 38 people. Consisting of 14 female students and 24 male students. This class action research was conducted at one elementary school in Coblong Subdistrict, Bandung City, West Java. The study was conducted for 3 months, starting from February to April 2018.

Data collection techniques used were observation and field notes. And the instruments used in this study are as follows.

\subsection{Learning Instruments}

\subsubsection{Lesson Plan}

The Lesson plan is designed as a basis or starting point for the implementation of learning. The lesson plans prepared in this classroom action research apply the conferencing approach in learning. Specifically by applying three levels in the core learning activities, including the beginning level, the middle level, and the final level.

\subsubsection{Student Worksheet}

Designing student worksheets to support student learning activities while learning. Where this worksheet will be designed so that this worksheet can condition students to interact or communicate with their group colleagues by helping each other in group work.

\subsection{Data Collection Instruments}

\subsubsection{Observation Ability of Cooperation Sheet}

This observation sheet is to measure the ability of students to cooperate and see the increase in the ability of students to work together in class during the learning process, especially in the process of discussion experienced by students.

\subsubsection{Observation Sheet for Teacher and Student Activities}

This observation sheet is to find out the appropriateness of the plan that has been prepared with the implementation as well as an indicator to find solutions to problems that arise in learning that must be followed up at the next meeting.

\subsubsection{Field Notes}

Field notes are used when learning takes place to complete the observational data. This field note is used as a data amplifier or in other words can help researchers in getting more data so that the results of this action or research will be more accurate.

While the procedure of data analysis is through quantitative and qualitative data analysis. Quantitative data is taken using average and percentage statistics. Whereas 
qualitative data was taken using techniques from Miles and Huberman consisting of three components (in Sugiyono, 2015, pp. 337-345), as follows.

1. The reduction of data is the activity of summarizing, choosing the main things, focusing on the important things, looking for themes and patterns and removing unnecessary.

2. Presentation of data, namely the activity of explaining research data that can be presented in the form of tables, graphs, pie charts, pictograms, and the like.

3. Drawing conclusions and verification, namely the activity of making research conclusions based on the results of data interpretation.

\section{Results And Discussion}

The learning implementation plan by applying the conferencing approach to improve students' collaborative abilities compiled by systematic researchers is by Permendikbud No. 22 of 2016. However, this RPP has improved from cycle I to cycle II and cycle III. Things that need to be improved include managing time and regulations when learning takes place. This means that the compilation of lesson plans cannot be good at the same time. Therefore, to be able to prepare lesson plans properly, it is necessary to be explored in advance about the theory of the preparation of lesson plans and class management. In preparing the learning implementation plan not only pay attention to teaching materials and learning methods that will be applied, but need to pay attention to other things.

The lesson plans that have been prepared previously serve as a guide in implementing learning. By applying the steps or levels of the conferencing approach the student activity increases compared to the student activity in the pre-cycle. In the precycle of student activities, only five activities are consisting of listening to the teacher's explanation, reading the text on the theme book, copying the text on the notebook, working on the questions on the theme book, and taking notes on the work to be done at home. But in the first cycle of student learning activities into seven activities consisting of listening to the teacher's explanation, discussing with groups, carrying out activities by the guidelines of the worksheet, working on problems in the worksheet, group presentations, and working on evaluation questions. And in cycle II and cycle III student learning activities eight activities are the same as the first cycle but the activity is added by recording tasks to be done at home. The diversity of student-centered learning activities can help improve students' collaborative abilities.

The results showed that the learning cycle I, cycle II and cycle III were better compared to pre-cycle because it could improve students' collaborative abilities. At the pre-cycle level of cooperation ability, grade IV SDN CST students were at the level of needing guidance, with the percentage of cooperative ability at $40.57 \%$. In the first cycle, the cooperation ability of the fourth-grade elementary school students was at the level of cooperation ability which was sufficient, with the percentage of the ability of cooperation equal to $53.80 \%$. The increase in the ability to cooperate in the first cycle is influenced by the conferencing approach that includes student learning activities. Besides, group learning is facilitated by structured tasks that are presented in the worksheet. There are quite a lot of tasks that need to be completed and the working time 
that doesn't take long makes students practice to divide tasks and work together so that the assignments can be completed on time. And the character of this fourth-grade elementary school student tends to like to compete to be a superior group, especially in completing group assignments. This capacity building for cooperation is dominated by each group leader because the group leader has a very important role in organizing and inviting members to learn and work together.

In the second cycle, the percentage of cooperation ability is $76.83 \%$. This increase is influenced by several things, the first is the conferencing approach that is applied in learning. Second, there are group learning rules that must be obeyed so that students become orderly and carry out activities in groups as they should. Third, the existence of learning experiences in a cycle I make students know what to do in cycle II learning. However, as in the first cycle, the significant increase in the ability to cooperate is still dominated by the leader of each group, although some students are members of the group that the ability to increase cooperation is also quite significant. Students who do not have a turn as group leaders do not get more opportunities to improve their collaborative skills as students become group leaders.

In cycle III the percentage of students' work abilities was $88.23 \%$. This increase is influenced by several things, such as in cycle II, the first is the conferencing approach that is applied in learning. Second, there are group learning rules that must be obeyed so that students become orderly and carry out activities in groups as they should. Third, the existence of learning experiences in cycle I and cycle II makes students know what to do in learning cycle III.

Based on the results of the percentage of students' collaborative abilities can be seen the comparison of the percentage of pre-cycle, cycle I, cycle II, and cycle III in the

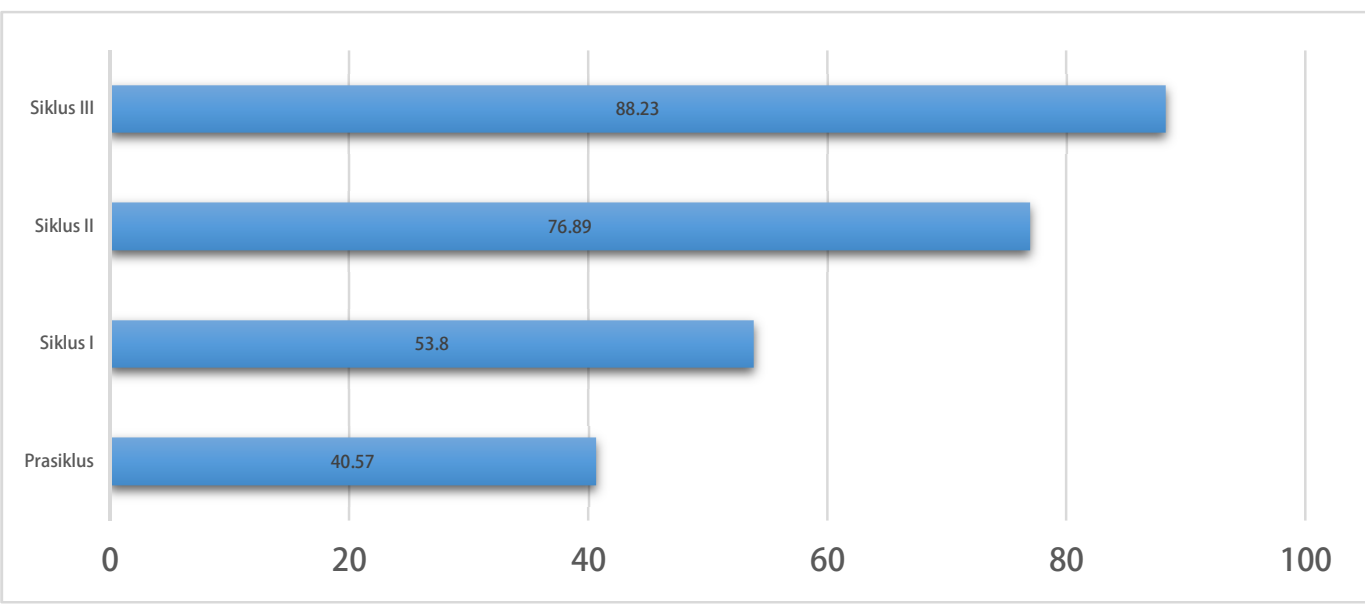
foll owi ng diag ram:

Picture 1. Comparison of Percentage of Pre-Cycle, Cycle I, Cycle II, and Cycle III

Based on the exposure to the increased ability to work together in cycles I, II and III above, the increase in the ability to cooperate in grade IV elementary school students is strongly influenced by the application of the conferencing approach to learning. This relates to the opinion of Lyesmana, et al (in Suherman, 2016, p.4) explaining that "... the 
conferencing approach is a form of approach where conference participants interact and communicate with one another". So that it can foster an attitude of cooperation, tolerance, and accept the opinions of others.

The relevant research from Zia Choerulwildan (2017) that the application of the conferencing approach can improve the discussion skills of fifth-grade elementary school students. The results showed that the first cycle of students' discussion skills reached $37.74 \%$, the second cycle $61.66 \%$, and in the third cycle $88.88 \%$. The results of this study indicate that there is an increase in discussion skills so that it will affect the ability of students to work together.

Meanwhile, the results of another study from Meti Kusuma Dewi (2017) showed that the application of the TGT (team game tournament) type of cooperative learning model could improve the cooperative skills of fifth-grade elementary school students. The results showed that the average cycle I could cooperate with students, namely $65 \%$, increasing in cycle II by $20 \%$ to $85 \%$. The results of these studies indicate that there is an increase in the ability to work together by applying group learning.

Classroom action research by applying a conferencing approach to improve the ability to cooperate with students in grade IV Elementary School is only carried out as much as III cycles. Reviewing the results of the third cycle of research shows the ability of cooperation in grade IV elementary school students has reached a percentage of $88.23 \%$, because based on the opinion of Sudjana $(2011$, p. 8) that "is said to be successful if it masters or can achieve about 75-80 percent of the goals or the value that should have been achieved. Therefore, this class action research is enough to be carried out as many as III cycles, because the percentage of cooperation ability of grade IV SD CST students has reached more than $80 \%$.

\section{Conclusion}

Learning Implementation Plan by applying the conferencing approach to improve the ability to collaborate with students in grade IV SDN CST the system refers to Permendikbud No. 22 of 2016. Even though the systematic RPP is the same as the systematic pre-cycle RPP, but it has differences in the core learning activities. The learning step by applying the conferencing approach consists of the beginning, middle, and final levels. Also, this lesson plan has improved from cycle I to cycle II and cycle III. Improvements include managing time in the lesson plan.

The implementation of learning in class IV SDN CST by applying a conferencing approach is better than the pre-cycle. Teacher and student activities become more diverse. Student activities include listening to the teacher's explanation, discussing groups, doing activities in accordance with the guidelines of the worksheet, working on questions in the worksheet, delivering the results of the discussion (presentation), reflecting on learning and drawing conclusions on learning, working on the evaluation of learning, and recording assignments to do at home. The teacher's activities include explaining the material, distributing worksheets, instructing students to discuss or talk, go around to each group and provide guidance and assessment, arrange group presentation activities, invite students to reflect and make conclusions of learning, 
provide evaluation questions, and give assignments for students to do at home. Increased student activity contributes to the improvement of their collaborative abilities

The application of the conferencing approach has succeeded in increasing the cooperation ability of grade IV SDN CST students. At the pre-cycle reached a percentage of $40.57 \%$. In the first cycle reached a percentage of $53.80 \%$. In the second cycle reached a percentage of $76.89 \%$. And in cycle III has increased again with a percentage of $88.23 \%$.

Based on the description above it can be stated that the application of the conferencing approach can improve the cooperation skills of fourth-grade elementary school students.

\section{References}

[1] Aqib, Z, dkk. (2017) . Penelitian Tindakan Kelas (PTK) TK/RA, SLB/SDLB. Yogyakarta : Ar-Ruzz Media.

[2] Arifah, F. (2017). Penelitian Tindakan Kelas. Yogyakarta : Araska.

[3] Arikunto. (2013). Prosedur Penelitian. Jakarta : Bumi Aksara.

[4] Hartati, T. (2009). Jurnal Pendidikan Dasar. Penerapan Pendekatan Conferencing dalam Pembelajaran Menulis di Sekolah Dasar, (11), hlm. 49-50.

[5] Isjoni. (2011). Cooperative Learning Mengembangkan Kemampuan Belajar Berkelompok. Bandung : Alfabeta.

[6] Sudjana. (2011) . Penilaian Hasil Proses Belajar Mengajar. Bandung : PT Remaja Rosdakarya.

[7] Sugiyono. (2015). Metode Penelitian Pendidikan. Bandung : Alfabeta.

[8] Suherman, W. (2016). Penerapan Pendekatan Conferencing Untuk Meningkatkan Keterampilan Berdiskusi Siswa Kelas V Sekolah Dasar. (Skripsi). Prodi PGSD, Fakultas Ilmu Pendidikan, Universitas Pendidikan Indonesia, Bandung.

[9] Widiasmoro, E. (2017). Masalah-Masalah Peserta Didik. Yogyakarta : Araska.

[10] Universitas Pendidikan Indonesia. (2017). Pedoman Penulisan Karya Tulis Ilmiah. Bandung : UPI. 